\begin{tabular}{|c|c|}
\hline $144 \quad$ of Accounting & MANAGEMENT SCIENCE \\
\hline $\begin{array}{l}\text { Volume 1, Nomor 1, Juni } 2020 \\
\text { P-ISSN: 2722-3132, E-ISSN: } 2722-3124 \\
\text { Website: http: pasca-umi.ac.id/index.php/jfa }\end{array}$ & 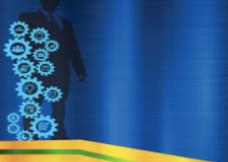 \\
\hline This work is licensed under a Creative Commons Attribution 4.0 International License. & $\theta=$ \\
\hline
\end{tabular}

\title{
Pengaruh Pengungkapan Corporate Social Responsibility, Karakter Eksekutif, Profitabilitas Dan Corporate Governance Terhadap Agresivitas Pajak Pada Perusahaan Manufaktur
}

\author{
Ika Irmawati ${ }^{1}$, Fadliah Nasaruddin ${ }^{2}$, Asriani Junaid ${ }^{3}$ \\ 1,2,3,4 Magister Akuntansi, Universitas Muslim Indonesia. \\ ${ }^{1}$ Koresponden Penulis, E-mail: ikhaachikaa2@gmai.com
}

\begin{abstract}
ABSTRAK
Penelitian ini bertujuan untuk menganalisis pengaruh luas pengungkapan corporate social responsibility, karakteristik eksekutif, profitabilitas, corporate governance terhadap agresivitas pajak. Corporate governance yang diproksikan dengan kepemilikan institusional, ukuran dewan komisaris dan komite audit terhadap agresivitas pajak. Agresivitas pajak diukur dengan effective tax rate. Penelitian ini juga menggunakan variabel kontrol yaitu ukuran perusahaan dan leverage. Penelitian ini merupakan penelitian kuantitatif dengan pendekatan deskriptif. Populasi dalam penelitian ini adalah perusahaan manufaktur sektor industri dasar dan kimia yang terdaftar di Bursa Efek Indonesia. Penentuan sampel penelitian berdasarkan metode purposive sampling dengan jumlah sampel sebanyak 75. Data yang digunakan dalam penelitian merupakan data sekunder yang diakses melalui www.idx.co.id. Analisis data menggunakan analisis regresi linear berganda untuk hipotesis corporate social responsibility, karakteristik eksekutif, profitabilitas, dan corporate governance. Hasil penelitian menunjukkan bahwa pengungkapan corporate social responsibility tidak berpengaruh terhadap agresivitas pajak, sedangkan karakteristik eksekutif dan corporate Governance berpengaruh negatif terhadap agresivitas pajak, dan profitabilitas berpengaruh positif terhadap agresivitas pajak.
\end{abstract}

Kata Kunci: Corporate Social Responsibility: Karakter Eksekutif: Profitabilitas; Corporate Governance

\begin{abstract}
This study aims to analyze the effect of corporate social responsibility disclosure, executive characteristics, profitability, corporate governance toward tax aggressiveness. Corporate governance is proxied with institutional ownership, the size of the board of commissioners and the audit committee on tax aggressiveness. Tax aggressiveness is measured by the effective tax rate. This research also used control variable that is firm size and leverage. The research is a quantitative research with a descriptive approach. The population in this study were manufacturing companies in the basic industrial sector and chemicals listed on the Indonesia Stock Exchange. The determination of the research sampel was based on the purposive sampling method with a total sample size of 75 . The data used in this study is secondary data which is accessed through www.idx.co.id. Data analysis used multiple linear regression for the corporate social responsibility, executive characteristics, profitability, and corporate governance. The result of the research indicate that the exposure of corporate social responsibility have noeffect on tax aggressiveness, executive characteristics and corporate governance have a negative effect on tax aggressiveness, and profitability have a positive effect on tax aggressiveness.
\end{abstract}

Keywords: Corporate Social Responsibility: Executive Character: Profitability; Corporate Governance 
Corporate Social responsibility (CSR) dianggap sebagai faktor utama dalam keberhasilan dan kelangsungan hidup perusahaan. Konsep tentang Corporate Social responsibility (CSR) mulai berkembang di Indonesia sehingga perusahaanperusahaan mulai menganggap penting memiliki tanggung jawab sosial dan lingkungan dalam menyelesaikan masalah-masalah sosial kemasyarakatan dan lingkungan, yang menarik untuk diamati dan diteliti yaitu apakah rasa tanggung jawab sosial perusahaan melalui aktivitas-aktivitas CSR yang dilakukan berhubungan dengan rasa tanggung jawab sosial perusahaan melalui pembayaran pajak dengan benar.

Penelitian mengenai pengaruh CSR terhadap agresivitas pajak sudah pernah dilakukan oleh Fionasari dkk (2017) hasil penelitiannya menemukan bahwa CSR tidak berpengaruh terhadap agresivitas pajak pada perusahaan yang listing di BEI. Berbeda dengan hasil penelitian tersebut, Handayani dkk (2018) meneliti tentang pengaruh CSR terhadap agresivitas pajak pada 20 perusahaan manufaktur sektor industri dasar dan kimia periode 2013-2015, dan hasilnya menemukan bahwa CSR berpengaruh positif terhadap agresivitas pajak.

Perusahaan dengan kegiatan CSR yang tidak bertanggung jawab lebih agresif dalam agresivitas pajak. Adiwibowo (2017) Corporate Social responsibility (CSR) berpengaruh signifikan terhadap agresivitas pajak. Hasil yang dtunjukkan dari beberapa penelitian tersebut berbeda dengan penelitian yang dilakukan oleh Toly dan Jessica (2014) menunjukkan bahwa luas pengungkapan CSR tidak berpengaruh terhadap aresivitas pajak, maksudnya apabila nilai luas pengungkapan CSR besar, maka belum tentu perusahaan akan semakin tidak agresif.

Perbedaan hasil-hasil dari penelitian tersebut merupakan salah satu alasan untuk menguji pengaruh CSR pada agresivitas pajak di Indonesia. Menurut Watson bahwa CSR seharusnya berpengaruh negatif signifikan terhadap agresivitas pajak karena perusahaan yang melakukan luas pengungkapan CSR untuk memenuhi kewajiban sosialnya dinilai akan memenuhi kewajiban ekonominya untuk membayar pajak sehingga agresivitas pajak seharusnya rendah. Adanya pendapat yang menyatakan bahwa pajak merupakan biaya bagi perusahaan dan pemilik perusahaan, sehingga membuat perusahaan tidak serta merta melakukan tindakan pajak agresif, hal ini dikarenakan tindakan pajak agresif dapat menimbulkan konsekuensi biaya lain, yaitu biaya akibat dari masalah yang timbul akibat adanya masalah keagenan (agency problem). Selain itu, mendirikan perusahaan keluarga juga menyiratkan konflik keagenan yang lebih besar antara pemegang saham mayoritas dan minoritas, konflik keagenan yang lebih kecil antara pemilik dan manajer, sifat dan tingkat konflik keagenan dapat mempengaruhi tindakan pajak agresif (Martani \& Sari, 2010).

Keputusan untuk melakukan agresivitas pajak merupakan hasil kebijakan perusahaan yang secara langsung. Adapun individu yang terlibat dalam pembuatan keputusan pajak adalah direktur pajak dan juga konsultan pajak perusahaan, sedangkan eksekutif (direktur utama atau presiden direktur) yang memilikikarakteristikistik berbeda-beda secara langsung atau tidak langsung juga berpengaruh terhadap segala keputusan yang terjadi dalam perusahaan sehingga karakteristikistik eksekutif dianggap faktor penting yang dapat mempengaruhi kebijakan yang diambil oleh eksekutif. Agresivitas pajak yang dilakukan 
perusahaan-perusahaan tentulah sangat merugikan negara. Pimpinan-pimpinan yang bertugas sebagai pengambil keputusan sangat berpengaruh penting terhadap hal tersbut, karena setiap pemimpin memiliki karakter yang berbeda antara pimpinan satu dengan pimpinan yang lainnya.

karakter eksekutif berpengaruh terhadap penghindaran pajak (Dyreng, 2010) yang menyimpulkan bahwa eksekutif memiiki peranan signifikan terhadap adanya agresivitas pajak perusahaan. Penelitian yang dilakukan oleh Carolina, et al (2014) menunjukkan bahwa hasil koefisien regresi berpengaruh negatif, yang artinya semakin eksekutif bersifat risk taker, maka semakin rendah nilai cash ETR perusahaan, itu berarti perusahaan tersebut sudah melakukan agresivitas pajak. Hal ini disebabkan karena keberanian eksekutif dalam mengambil risiko untuk memaksimalkan nilai perusahaan.

Selain dari karakteristik eksekutif, kepemilikan keluarga juga mempengaruhi suatu perusahaan dalam melakukan kewajiban perpajakan, seperti penelitian yang dilakukan oleh Chen at al (2010) menemukan bahwa tingkat keagresifan tindakan pajak pada perusahaan keluarga lebih kecil dibanding perusahaan non keluarga, hal ini terjadi karena diduga kepemilikan keluarga lebih rela membayar pajak lebih tinggi, dari pada harus membayar denda pajak dan menghadapi kemungkinan rusaknya reputasi perusahaan akibat audit dari fiskus pajak. Sedangkan penelitian yang dilakukan oleh (Martani \& Sari 2010) yang menunjukkan bahwa kepemilikan keluarga cenderung bertindak lebih agresif dalam perpajakan dari pada perusahaan non keluarga, hal ini kemungkinan disebabkan keuntungan yang diperoleh perusahaan berupa penghematan pajak.

Hubungan kepemilikan keluarga dengan tindakan pajak agresif diduga berkaitan dengan masalah corporate governance perusahaan. Penerapan corporate governance sangat diharapkan mampu mengatasi masalah agensi yang dialami oleh perusahaan, masalah agensi ini timbul karena adanya asimetri informasi akibat pemisahan kepemilikan dengan manajemen perusahaan dan mampu meningkatkan kinerja perusahaan dengan meningkatkan efisiensi pembayaran pajak perusahaan.

Pengaruh pajak begitu besar terhadap negara dan merupakan hal yang wajib dipahami untuk kepentingan bersama, jenis karakteristik individu yang memiliki fungsi dalam pengambilan keputusan manajemen perusahaan serta bagaimana pengaruh pimpinan perusahaan dalam menjalankan fungsinya dapat mempengaruhi manajemen dalam menyusun laporan keuangan yang berkualitas. Perusahaan yang telah menerapkan karakteristikistik corporate governance diharapkan mampu menghasilkan kinerja yang baik dan efisien sehingga corporate governance dapat memberikan perlindungan efektif bagi para pemegang saham dan stakeholder.

Isu sentral dari corporate governance yaitu berdasarkan pemisahan antara kepemilikan dan kontrol perusahaan. Teori Agensi yang menjelaskan secara komprehensif mengenai konflik kepentingan antara manajemen selaku agen dan pemegang saham selaku principal yang biasa disebut sebagai masalah agensi. Dalam menjembatani konflik tersebut dibutuhkan biaya (agency cost). Seperti yang telah dijelaskan sebelumnya bahwa dengan adanya corporate governance, agency cost dapat dikurangi. Pengurangan ini lebih mengefektifkan kinerja perusahaan sehingga mampu memaksimalkan laba. Peningkatan kinerja perusahaan tercermin dalam pengelolaan 
pajak perusahaan. Hal ini sesuai dengan tujuan penerapan corporate governance untuk memaksimalkan nilai pemegang saham dalam perusahaan.

Corporate governance dan agresivitas pajak memiliki sebuah hubungan timbal balik, karena perusahaan merupakan wajib pajak sehingga karakteristikistik corporate governance mempengaruhi perusahaan dalam memenuhi kewajiban pajaknya, tetapi disisi lain agresivitas pajak tergantung pada dinamika dari corporate governance dalam suatu perusahaan. Beberapa karakteristikistik corporate governance dalam perusahaan akan menentukan penerapan manajemen pajak (Sari dan Martani, 2010).

Karakteristikistik corporate governance ketiga yaitu komite audit yang berfungsi sebagai pengawas dalam pembuatan laporan keuangan dan melakukan pengawasan internal. Adanya pengawasan lebih yang dilakukan oleh komite audit akan membuat manajemen lebih berhati-hati dalam mengambil keputusan bagi perusahaan, termasuk yang terkait dengan perpajakan. Sama halnya dengan keberadaan komisaris independen, manajemen akan berusaha untuk tidak melakukan atau menurunkan tingkat agresivitas pajak perusahaan. perusahaan, termasuk yang terkait dengan perpajakan. Sama halnya dengan keberadaan komisaris independen, manajemen akan berusaha untuk tidak melakukan atau menurunkan tingkat agresivitas pajak perusahaan.

Dalam penelitian ini saya akan menggunakan Variabel kontrol untuk mengendalikan agar pengaruh variabel independen terhadap agresivitas pajak tidak dipengaruhi faktor lain yang tidak diteliti. Variabel kontrol yang akan digunakan yaitu Size dan Leverage. Pengaruh perusahaan dalam membayar pajak juga dipengaruhi oleh ukuran perusahaan (Size). Semakin besar aset yang dimiliki perusahaan maka semakin besar ukuran perusahaan. Besar kecilnya aset juga memengaruhi jumlah produktiftas perusahaan, sehingga laba yang dihasilkan perusahaan akan mempengaruhi tingkat pembayaran pajak. Perusahaan yang tergolong perusahaan kecil tidak dapat mengelola pajak dengan optimal dikarenakan kekurangan ahli dalam hal perpajakan, berbeda dengan perusahaan yang tergolong perusahaan besar yang memiliki sumber daya yang lebih besar sehinggah dapat mengelolah pajak.

Faktor lain yang mempengaruhi agresivitas pajak perusahaan adalah leverage. Leverage merupakan suatu ukuran seberapa besar aset yang dimiliki perusahaan dibiayai oleh hutang. Leverage menunjukkan penggunaan hutang untuk membiayai investasi. Perusahaan menggunakan hutang akan menimbulkan adanya bunga yang harus dibayar. Semakin tinggi leverage maka semakin tinggi resiko perusahaan, sehinggah mempengaruhi laba bersih perusahaan. Menurut (Hadi dan Mongoting, 2014) terdapat hubungan yang postif antara agresivitas pajak dengan leverage karena perusahaan menggunakan beban bunga untuk mengurangi laba bersih sehingga beban bunga juga mengurangi pajak.

Penelitian ini dimotivasi dengan banyaknya kasus agresivitas pajak yang dilakukan perusahaan-perusahaan ternama. Selain itu adanya ketidakkonsistenan dari penelitian sebelumnya terkait penelitian agresivitas pajak sehingga menjadi konsep dasar penelitian ini dilakukan. Oleh karena itu, dalam penelitian ini peneliti ingin meneliti lebih lanjut mengenai luas pengungkapan CSR, karakteristik eksekutif, kepemilikan keluarga, profitabilitas, dan corporate governance terhadap agresivitas 
pajak, khususnya di Indonesia. Untuk variabel corporate governance di proksikan dengan kepemilikan institusional, ukuran dewan komisaris dan komite audit.

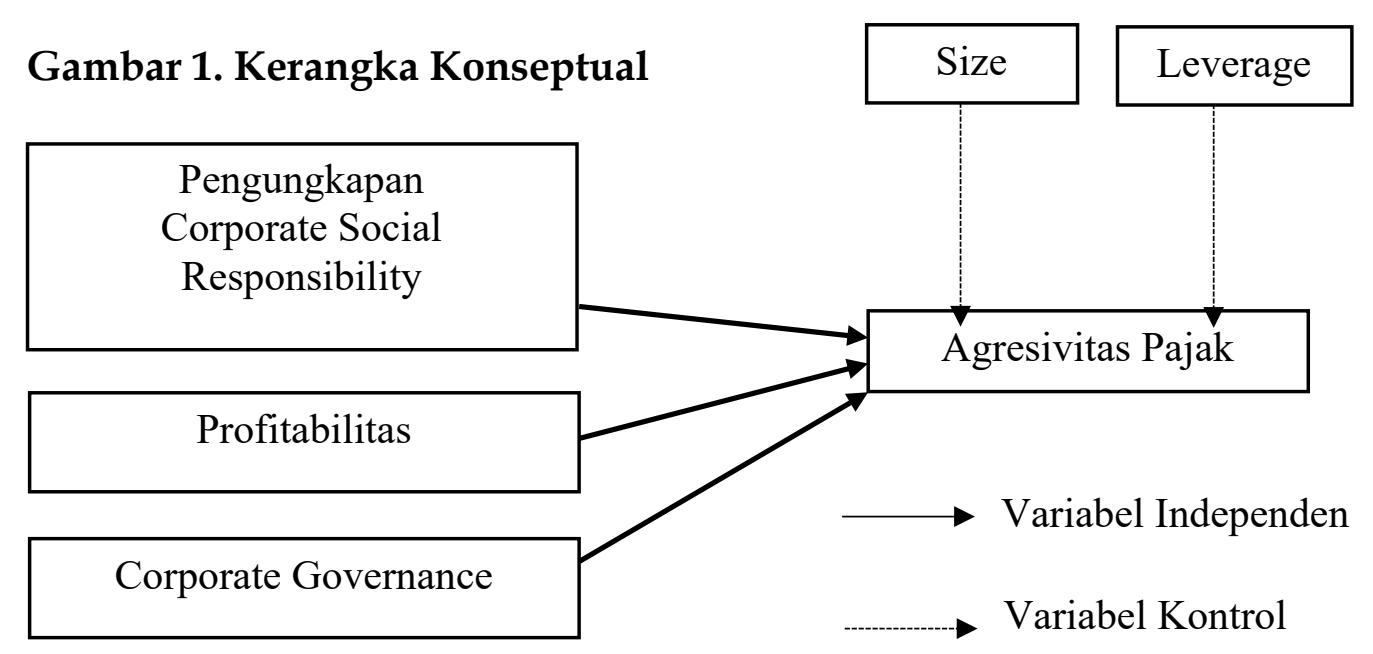

Penelitian ini bertujuan untuk menguji hipotesis yang menjelaskan pengaruh variabel independen terhadap variabel dependen. Sehingga jenis penelitian ini adalah uji hipotesis. Hipotesis penelitian dikembangkan berdasarkan teori-teori yang berkaitan dengan topik penelitian dan kemudian akan dilakukan pengujian berdasakan teknik analisis yang sesuai.

Sifat penelitian ini adalah kausal yang bertujuan untuk mengukur kuat hubungan dan pengaruh antar variabel dalam penelitian. Sebelum mengukur kuat hubungan dan pengaruh antara variabel independen dan variabel dependen, setiap variabel didefinisikan dan diukur berdasarkan proksinya.

Pengujian model menggunakan regresi berganda, variabel dependennya adalah agresivitas pajak dan variabel independenya adalah luas pengungkapan Corporate Social Responsibility, karakteristikistik eksekutif (Corporate Risk), profitabilitas, kepemilikan keluarga dan Corporate Governance yang diproksikan dengan kepemilikan institusional, ukuran dewan komisari dan komite audit variabel kontrol adalah ukuran perusahaan dan leverage. Uji hipotesis pada model ini, dijabarkan dalam persamaan regresi berikut:

$Y=\beta 0+\beta 1 X 1+\beta 2 X 2+\beta 3 X 3+\beta 4 X 4+\beta 5 X 5+\beta 6 X 6+e$

Keterangan:

$\mathrm{Y} \quad=$ Agresivitas Pajak

X1 = Pengungkapan Corporate Social Responsibility

$\mathrm{X} 2=$ Karakteristik eksekutif (corporate risk)

$\mathrm{X} 3=$ Profitabilitas perusahaan

$\mathrm{X} 4=$ Corporate Governance 


$$
\begin{aligned}
& X 5=\text { Ukuran perusahaan } \\
& X 6 \quad=\text { Leverage perusahaan } \\
& \beta 0 \quad=\text { Konstanta } \\
& \beta 1-\beta 7=\text { koefisien regresi } \\
& \text { e } \quad=\text { Error }
\end{aligned}
$$

\section{A. Hasil Penelitian}

Uji hipotesis dalam penelitian ini menggunakan analisis regresi berganda. Ringkasan hasil regresi berganda disajikan pada tabel 6. di bawah ini:

Tabel 1. Hasil Regresi Berganda



Pada tabel 6., koefisien determinasi yang ditunjukkan oleh R2 dari persamaan regresi menghasilkan nilai sebesar 0.314. Nilai tersebut dapat dijelaskan bahwa $31.4 \%$ dari variabel independen yang terdiri dari pengungkapan Corporate Social Responsibility, karakteristikistik eksekutif (Corporate Risk), profitabilitas, dan Corporate Governance yang diproksikan dengan kepemilikan institusional, ukuran dewan komisaris dan komite audit serta variabel kontrol adalah ukuran perusahaan dan leverage. Sisanya $68.6 \%$ yang dijelaskan oleh variabel lain di luar model. Hal ini mengartikan bahwa masih ada faktor-faktor lain yang sangat berpengaruh terhadap variabel agrevitas pajak. Pada uji signifikansi simultan yang ditunjukkan oleh Fstatistic, nilai yang dihasilkan oleh persamaan regresi sebesar 3.820 dengan signifikansi di bawah a $=0.05$. Hal itu dapat dijelaskan bahwa pengungkapan Corporate Social Responsibility, karakteristikistik eksekutif (Corporate Risk), profitabilitas, dan Corporate Governance serta variabel kontrol adalah ukuran perusahaan dan leverage secara simultan berpengaruh terhadap variabel agrevitas pajak.

Hasil regresi berganda pada tabel 6. diperoleh konstanta dari persamaan regresi sebesar 0.103 . Hasil nilai konstanta tersebut menyatakan bahwa tanpa ada pengaruh 
variabel independen yang terdiri dari luas pengungkapan Corporate Social Responsibility, karakteristikistik eksekutif (Corporate Risk), profitabilitas, kepemilikan keluarga dan Corporate Governance yang diproksikan dengan kepemilikan institusional, ukuran dewan komisari dan komite audit. Variabel kontrol adalah ukuran perusahaan dan leverage, rata-rata perusahaan akan meningkatkan agrevitas pajaknya sebesar 0.299.

Pada hasil uji hipotesis, ada tujuh hipotesis yang dibangun dalam penelitian ini. Berikut ringkasan hasil uji hipotesis yang ditunjukkan pada tabel 7.

Tabel 2. Hasil Uji Hipotesis

\begin{tabular}{ccccc} 
Hipotesis & Koefisien & $\begin{array}{c}\text { Prediksi } \\
\text { Arah }\end{array}$ & Signifikansi & Hasil \\
\hline H1 & 0.103 & Positif & Tidak Signifikan & Ditolak \\
\hline H2 & -0.354 & Negatif & Signifikan & Diterima \\
\hline H3 & 0.401 & Positif & Signifikan & Ditolak \\
\hline H4 & -0.351 & Negatif & Signifikan & Diterima \\
\hline
\end{tabular}

\section{Pengungkapan CSR}

Koefisien regresi variabel CSR sebesar 0.103 menyatakan bahwa jika pengungkapan CSR meningkat sebesar $1 \%$, agrevitas pajak akan menurun sebesar $0.103 \%$. Pada tingkat signifikansi, CSR memiliki signifikansi sebesar 0.261 yang berada di atas a $=0.05$ sehingga hasilnya dapat disimpulkan bahwa pengungkapan CSR tdk berpengaruh terhadap agrevitas pajak. Hasil tersebut menolak H1 yang menyatakan bahwa CSR berpengaruh negatif terhadap agrevitas pajak.

2. Karakteristikistik Eksekutif (Risiko Perusahaan)

Koefisien regresi variabel CR sebesar -0.354 menyatakan bahwa jika risiko perusahaan meningkat sebesar $1 \%$, agrevitas pajak akan meningkat sebesar $0.354 \%$. Pada tingkat signifikansi, CR memiliki signifikansi sebesar 0.005 yang berada di bawah a $=0.05$ sehingga hasilnya dapat disimpulkan bahwa karakter eksekutif berpengaruh negatif terhadap agrevitas pajak. Hasil tersebut menerima H2 yang menyatakan bahwa karakteristikistik eksekutif yang diukur menggunakan risiko perusahaan berpengaruh terhadap agrevitas pajak.

3. Profitabilitas

Koefisien regresi variabel ROA sebesar 0.401 menyatakan bahwa jika profitabilitas meningkat sebesar $1 \%$, agrevitas pajak akan menurun sebesar $0.401 \%$. Pada tingkat signifikansi, ROA memiliki signifikansi sebesar 0.002 yang berada di bawah a $=0.05$, tetapi memiliki arah yang positif. Hasil tersebut menolak H3 yang menyatakan bahwa profitabilitas berpengaruh negatif terhadap agrevitas pajak.

\section{Corporate Governance}

Koefisien regresi variabel CG sebesar -0.351 menyatakan bahwa jika Corporate Governance meningkat sebesar $1 \%$, agrevitas pajak akan menurun sebesar $0.351 \%$. Pada tingkat signifikansi, CG memiliki signifikansi sebesar 0.012 yang berada di bawah $a=0.05$ sehingga hasilnya dapat disimpulkan bahwa Corporate Governance 
berpengaruh negatif terhadap agrevitas pajak. Hasil tersebut menerima H4 yang menyatakan bahwa Corporate Governance berpengaruh negatif terhadap agrevitas pajak.

\section{Ukuran Perusahaan}

Koefisien regresi variabel ukuran perusahaan 0.221 menyatakan bahwa jika ukuran perusahaan meningkat sebesar $1 \%$, agrevitas pajak akan menurun sebesar $0.221 \%$. Pada tingkat signifikansi, ukuran perusahaan sebagai variabel kontrol berpengaruh signifikan terhadap agrevitas pajak yang ditunjukkan oleh signifikansi sebesar 0.039 yang berada di bawah $a=0.05$.

\section{Leverage}

Koefisien regresi variabel leverage 0.243 menyatakan bahwa jika leverage meningkat sebesar $1 \%$, agrevitas pajak akan menurun sebesar $0.243 \%$. Pada tingkat signifikansi, leverage sebagai variabel kontrol berpengaruh terhadap agrevitas pajak yang ditunjukkan oleh signifikansi sebesar 0.029 yang berada di bawah $a=0.05$.

\section{B. Pembahasan}

\section{Pengaruh pengungkapan CSR terhadap Agrevitas Pajak}

Hasil uji hipotesis H1 menunjukkan bahwa pengungkapan CSR menunjukkan hasil positif yang tidak signifikan pada agrevitas pajak. Hasil tersebut tidak mendukung rumusan hipotesis $\mathrm{H} 1$ yang menyatakan bahwa luas pengungkapan CSR berpengaruh negatif terhadap agrevitas pajak.

Pengungkapan berkaitan dengan masalah seberapa banyak informasi yang harus diungkapkan. Pengaruh positif antara luas pengungkapan CSR dan agresivitas pajak dapat diartikan bahwa semakin tinggi tingkat pengungkapan CSR, maka belum tentu akan semakin rendah tingkat agrevitas pajak. Hasil penelitian ini sejalan penelitian yang dilakukan oleh Landry et al (2013) yang menemukan bahwa CSR tidak berpengaruh signifikan terhadap agresivitas pajak pada perusahaan di Canada dan hasil penelitian Toly dan Jessica (2014) menunjukkan bahwa luas pengungkapan CSR tidak berpengaruh terhadap agresivitas pajak, maksudnya apabila nilai luas pengungkapan CSR besar, maka belum tentu perusahaan akan semakin tidak agresif.

Sebaliknya, Lanis dan Richardson (2012), menyatakan bahwa aktivitas CSR yang dilakukan oleh perusahaan secara konsisten dapat mengurangi agresivitas pajak perusahaan karena perusahaan yang melakukan luas pengungkapan CSR untuk memenuhi kewajiban sosialnya dinilai juga akan memenuhi kewajiban ekonominya untuk membayar pajak sehingga agresivitas pajak seharusnya rendah. Perbedaan ini dapat dikarenakan perbedaan item pengungkapan dalam penelitian Lanis dan Richardson adalah pengungkapan menurut standar luar negeri yaitu GRI. Sedangkan item pengungkapan CSR yang sesuai dengan kondisi di Indonesia adalah menurut BAPEPAM. Terlebih lagi kondisi di Indonesia pengungkapan CSR yang dilakukan oleh perusahaan masih bersifat umum dan belum rinci.

Di bawah kerangka teori legitimasi, perusahaan yang melakukan agresivitas pajak memerlukan luas pengungkapan informasi tambahan mengenai CSR untuk memenuhi harapan masyarakat. Dengan kata lain, perusahaan yang tidak terlibat CSR mendorong untuk melakukan tindakan agresivitas pajak yang lebih tinggi. Hal 
ini terjadi karena perusahaan yang melakukan tindakan agresivitas pajak kurang tertarik untuk menerapkan CSR secara baik di perusahaan.

\section{Pengaruh Karakteristik Eksekutif terhadap Agrevitas Pajak}

Hasil uji hipotesis $\mathrm{H} 2$ menunjukkan bahwa variabel Karakteristik Eksekutif diproksikan dengan Corporate Risk berpengaruh terhadap agresivitas pajak. Hasil tersebut menerima hipotesis $\mathrm{H} 2$ menyatakan bahwa karakteristik eksekutif berpengaruh terhadap agresivitas pajak. Hal ini sesuai dengan teori yang menyatakan bahwa karakteristik eksekutif lebih tinggi mengambil resiko dalam hal keputusan perusahaan termasuk tindakan agresivitas pajak.

Hasil penelitian ini sejalan dengan penelitian yang dilakukan oleh Ajie (2015) yang menyatakan bahwa eksekutif merupakan individu yang menempati sebuah posisi penting dalam sistem kepemimpinan di dalam perusahaan dan organisasi. Eksekutif memberikan pengaruh terhadap organisasi yang dipimpinnya sehingga memiliki pengaruh yang cukup besar kepada perusahaan serta pengaruh dalam pengambilan keputusan yang memiliki resiko tinggi.

Penelitian ini juga sejalan dengan penelitian yang dilakukan Dyreng et al (2010), menyatakan bahwa eksekutif yang memiliki karakteristik Eksekutif yang diproksikan dengan risiko perusahaan memiliki pengaruh yang positif terhadap agresivitas pajak. Hasil pengujian secara statistik menunjukkan bahwa hasil koefisien regresi yang negatif, artinya semakin eksekutif bersifat risk taker, maka semakin rendah nilai cash ETR perusahaan yang berarti perusahaan melakukan agresivitas pajak yang tinggi. Hal ini disebabkan karena keberanian eksekutif untuk mengambil risiko dalam memaksimalkan nilai perusahaan.

Di bawah kerangka teori Agensi, pengelolaan perusahaan harus diawasi untuk memastikan pengelolaan dilakukan dengan penuh kepatuhan terhadap ketentuan yang berlaku. Sistem manajemen risiko dan pengendalian internal yang efektif memungkinkan dewan komisaris melakukan monitoring dan mengelola risiko agar lebih baik, Dimana dari hasil penelitian peneliti karakter eksekutif berpengaruh terhadap tindak agresivitas pajak yang dapat merugikan perusahaan.

\section{Pengaruh Profitabilitas terhadap Agrevitas Pajak}

Hasil uji hipotesis H3 menunjukkan bahwa Profitabilitas berpengaruh signifikan antara variabel profitabilitas dengan agresivitas pajak, yang artinya, semakin tinggi nilai profitabilitas yang dimiliki perusahaan maka semakin tinggi agresivitas pajak yang dilakukan oleh perusahaan karena semakin tinggi laba yang didapatkan perusahaan maka semakin tinggi juga pajak yang akan dibayarkan.

Di dalam teori agensi, adanya konflik kepentingan antara pemilik perusahaan dengan manajemen, hal ini muncul karena keinginan manajemen untuk melakukan tindakan sesuai dengan kepentingannya dan dapat mengorbankan kepentingan prinsipal dalam mendapatkan profitabilitas perusahaan. Di mana kinerja real manajemen dapat dilihat dari pencapaian EBITDA dalam laporan tutup buku perusahaan.

\section{Pengaruh Corporate Governance terhadap Agrevitas Pajak}

Hasil uji hipotesis H4 menunjukkan bahwa corporate governance berpengaruh negatif terhadap agresivitas pajak. Hipotesis ini diproksikan dalam kepemilikan 
institusional, dewan komisaris, dan komite audit. Penelitian ini sejalan Pradnyanita dan Sari (2015) dengan kepemilikan oleh investor-investor institusional tidak tentu memberikan kontrol kepada manajemen untuk melakukan tindakan agresivitas pajak. Hal ini bisa saja karena kepemilikan institusional memberikan kepercayaan pengawasan dan pengelolaan perusahaan kepada dewan komisaris, sehingga ada atau tidaknya kepemilikan institusional tetap saja melakukan tindakan agresivitas pajak. Penelitian ini juga mendukung penelitian Dewi dan Jati (2014) dan Fadhilah (2014) yang menyatakan bahwa kepemilikan institusional tidak memiliki pengaruh pada agresivitas pajak. Ukuran Dewan Komisaris berpengaruh negatif terhadap agresivitas pajak. Semakin besar ukuran dewan komisaris maka agresivitas pajak akan menurun. Hasil penelitian ini menerima hipotesis H6. Penelitian ini sejalan dengan penelitian Ajie (2015), ukuran dewan komisaris berpengaruh negatif terhadap agresivitas pajak. Hal ini menunjukkan bahwa apabila komisaris independen mengalami peningkatan maka agresivitas pajak menurun. Dewan komisaris independen melakukan pengawasan terhadap manajemen perusahaan sehingga dapat mencegah adanya tindakan agresivitas pajak yang terjadi di perusahaan.

Komite Audit berpengaruh positif terhadap agresivitas pajak. Semakin tinggi keberadaan komite audit dalam perusahaan maka meningkatkan kualitas corporate governance sehingga akan menurunkan adanya tindakan agresivitas pajak perusahaan. Hal ini berarti bahwa keberadaan komite audit yang fungsinya untuk meningkatkan integritas dan kredibilitas pelaporan keuangan dapat berjalan dengan baik karena ada dukungan dari seluruh elemen dari dalam perusahaan. Hal ini diduga dapat terjadi karena pengawasan dan saran-saran yang diberikan komite audit diterima, sehingga memberikan pengaruh terhadap jumlah pajak perusahaan atau diduga karena komunikasi dengan pihak manajemen perusahaan, dewan komisaris dan pihak- pihak terkait berjalan lancar sehingga efektivitas komite audit meningkat. Penelitian ini sejalan dengan Ajie (2015) yang menyatakan bahwa komite audit berpengaruh positif signifikan terhadap agresivitas pajak. Hasil penelitian ini tidak sejalan dengan penelitian Kurniasih dan Sari (2011), menunjukkan bahwa keberadaan komite audit tidak berpengaruh terhadap agresivitas pajak.

Di dalam teori agensi, pengelolaan perusahaan harus diawasi untuk memastikan pengelolaan dilakukan dengan penuh kepatuhan terhadap ketentuan yang berlaku. Di sini kita dapat melihat apabila dewan komisaris, komite audit, dan kepemilikan institusional berperan baik dan efektif dalam pengawasan perusahaan maka resiko tindak agresivitas pajak yang merugikan perusahaan tidak akan terjadi. Dimana dari hasil penelitian kita melihat corporate governance berpengaruh apabila ada tindak agresivitas pajak dalam lingkup perusahaan.

Penelitian ini bertujuan untuk menguji dan memperoleh bukti empiris pengaruh kecerdasan emosional dan karakteristik personal auditor terhadap kualitas audit. Berdasarkan analisis data dan pembahasan yang telah dilakukan maka diperoleh hasil sebagai berikut:

1) Berdasarkan hasil pengujian hipotesis ditemukan bahwa kecerdasan emosional berpengaruh positif dan signifikan terhadap kualitas audit yang dilakukan oleh 
auditor. Artinya semakin tinggi tingkat kecerdasan emosional seseorang, maka kualitas audit yang dihasilkan akan semakin baik pula.

2) Berdasarkan hasil pengujian hipotesis ditemukan bahwa karakteristik personal berpengaruh negatif dan tidak signifikan terhadap kualitas audit yang dihasilkan. Maknanya yaitu karakteristik seseorang tidak mempengaruhi hasil dari auditnya. Karena dalam audit, sudah terdapat standar yang harus ditaati.

Adiwibowo, S. (2017). Pengaruh Corporate Social Responsibility terhadap Penghindaran Pajak Perusahaan. Departemen Akuntansi Fakultas Ekonomika dan Bisnis Universitas Diponegoro. Semarang

Ajie, R. (2015). Pengaruh Karakteristik Eksekutif, Kepemilikan Keluarga, Profitabilitas dan Corporate Governance Terhadap Agresivitas Pajak Di Indonesia. Fakultas Ekonomi Universitas Muhammadiyah. Yogyakarta

Chen, S., Chen, X. Q dan Shevlin, T. (2010). Are Family firms more tax aggressiveness than non-family firms? Journal of financial economics., 95, 41-61

Dewi, K., dan Jati, I.K. (2014). Pengaruh Karakteristikistik Eksekutif, Karakteristikistik Perusahaan, dan Corporate Governance pada Tax Avoidance di Bursa Efek Indonesia. E-Jurnal Akuntansi. ISSN 23028556. Vol. 6, No. 2. pp. 249-260. Fakultas Ekonomi dan Bisnis Universitas Udayana. Bali.

Dyreng, Scott D.; Hanlon, Michelle; Maydew Edward L. (2010). The Effect of Executives on Corporate Tax Avoidance, The Accounting Review, 85, 11631189

Hadi, J. \& Mangoting. (2014). Pengaruh Struktur Kepemilikan dan Karakteristik Dewan terhadap Agresivitas Pajak. Tax \& Accounting Review, VOL 4, NO 2, 2014. Universitas Kristen Petra

Handayani, S., dan Ramadhani. (2018). Pengaruh Agresivitas Pajak terhadap Corporate Social Responsibility dengan Variabel Kontrol Return on Asset dan Leverage. Universitas Sultan Agung Tirtayasa

Lanis, R. and G. Richardson. (2012). Corporate Social Responsibility and Tax Aggressiveness: a Test of Legitimacy Theory. Accounting, Auditing \& Accountability Journal, Vol. 26 Issue: 1, pp.75-100, doi: 10.1108/09513571311285621.

Martani, D., dan Sari. (2010). Ownership Characteristics, Corporate Governance, and Tax Aggressiveness. The 3rd Accounting \& The 2nd Doctoral Colloquium. Faculty of Economics Universitas Indonesia. 